\title{
VOX EVANGELICA
}

Vol. VII 1971

BIBLICAL AND

HISTORICAL ESSAYS

published by

\section{LONDON BIBLE COLLEGE}

Includes the Laing Lecture by

Prof. F. F. Bruce, MA, DD.

$48 p$. plus postage $12 p$.

(Some previous essays still available)

LBC, Green Lane, Northwood, Middx.

\section{SCOTTISH JOURNAL OF THEOLOGY}

is one of forty-nine learned journals published by Cambridge University Press.

A descriptive catalogue of Cambridge journals with details of back volumes is available from the London and New York offices of the Press.

Cambridge journals may be ordered from a bookseller or direct from the publishers.

\section{CAMBRIDGE UNIVERSITY PRESS}

Bentley House, 200 Euston Road, London NW1 2DB 32 East 57th Street, New York, N.Y.10022 


\section{NOTES FOR GONTRIBUTORS}

Contributions and editorial correspondence should be sent to one of the editors: Rev. Professor T. F. Torrance, 37 Braid Farm Road, Edinburgh, EHIO 6LE, Scotland; Rev. Professor J. K. S. Reid, Don House, 46 Don Street, Aberdeen, AB2 IUU, Scotland.

Submission of an article is taken to imply that it has not previously been published in English, or is not being considered by another journal for publication in English. In the interests of authors, copyright is normally assigned to the Cambridge University Press. The average length of articles is 5000 words. Although longer articles are accepted, those in excess of 10,000 words cannot be considered.

Contributions (articles and reviews) should be clearly typed in double spacing, and on one side of the paper only. The rule about double spacing applies also to footnotes, which should be used sparingly. Cross-references within the article offered should not be included.

Notes for the editors and instructions for the printer should be attached on separate sheets. Contributors should keep one copy of the typescript for use in correcting proofs.

Contributors from the United States may use U.S. spellings. Greek and Hebrew words need not be transliterated. Capitalisation should be kept to a minimum; and in particular should not be used in pronouns referring to the Deity.

First proofs of articles and article reviews may be read and corrected by contributors, and should normally be returned to the organising editor within ten days of receipt. Correction should be confined to , errors of the printer. More extensive correction can be made only with the concurrence of an editor. No proofs of reviews will be sent.

Contributors of articles and article reviews (but not of reviews) receive 25 free offprints. Extra copies may be bought according to an agreed scale of charges, provided that these are ordered at the time of returning corrected proofs. 


\section{GONTENTS}

Lonergan's view on theology: an outline, by William E. REISER (Worcester, Mass.)

The theology of themes, by J. M. Hull (Birmingham)

The image of God in Adam and the restoration of man in Jesus Christ, by Richard Prins (Grand Rapids, Michigan)

Some principles for reconstructing a doctrine of the imitation of Christ, by E. J. TinsLEY (Leeds)

The authority of grace in the theology of P. T. Forsyth, by B. G. WORrall (London)

Ministry and ordination according to Reformed theology, by J. J. von Allmen (Neuchâtel)

\section{REVIEWS}

PANNENBERg: Basic Questions in Theology, vol. I

MURDOCH: The Sovereignty of

Good. FURLONG: Travelling In

DOWNIE: Roles and Values

Austin: Waves, Particles, and

Paradoxes

HICK : Evil and the God of Love

EBELING: Luther: An Introduction

to his Thought. FRIEDENTHAL:

Luther. PELIKAN: Spirit versus

Structure: Luther and the

Institutions of the Church

TEILHARD DE CHARDIN: Hymn of

the Universe and Let Me

Explain

whyBRay: The Heavenly Counsellor

in Isaiah xl 13-14

PRITCHARD: Ancient Near Eastern

Texts relating to the Old Testa-

ment

JEREMIAS: New Testament

Theology, pt. I
KÄsemann: Perspectives on Paul 108

89 MINEAR: The Obedience of Faith 1 II HARveY: The New English Bible: Companion to the New Testament

GASQUE and MARTIN (eds.): Apostolic

History and the Gospel

95 MARKUS: Saeculum: History and

Society in the Theology of St.

Augustine

GAVE: Devotional Poetry in France,

c. $1570-1613$

116

BERKOUWER: The Sacraments 118

CLIFFORD: Now is the Time $\quad 120$

BOYD: What is Christianity? $\quad$ I21

WESSON (ed.): Experiments in

Renewal

122

BRown: The Ecumenical Revolution

STALKER: The Spirit and Material 125

IO6 BOOKS RECEIVED

127

(C) Cambridge University Press, 1972 